\title{
Review
}

\section{Using Serratia plymuthica to control fungal pathogens of plants}

\section{David De Vleesschauwer and Monica Höfte*}

Address: Laboratory of Phytopathology, Department of Crop Protection, Faculty of Bioscience and Engineering, Ghent University, Coupure Links 653, B-9000 Gent, Belgium.

*Correspondence: Monica Höfte. Email: monica.hofte@ugent.be

$\begin{array}{ll}\text { Received: } & 20 \text { April } 2007 \\ \text { Accepted: } & 26 \text { June } 2007\end{array}$

doi: 10.1079/PAVSNNR20072046

The electronic version of this article is the definitive one. It is located here: http://www.cababstractsplus.org/cabreviews

(C) CABI Publishing 2007 (Online ISSN 1749-8848)

\begin{abstract}
Interest in biological control of plant pathogens has increased in recent years fuelled by trends in agriculture towards greater sustainability and public concerns over the use of hazardous pesticides in the environment. Most studies on the biological control of fungal plant pathogens have tended to focus on the use of antagonistic rhizobacterial strains belonging to the genus Pseudomonas or Bacillus. However, the development of biocontrol products based on isolates belonging to the Gram-negative genus Serratia is now gaining momentum. Serratia plymuthica is a ubiquitous bacterium that has been preferentially recovered from rhizospheres all over the world, both as a free-living and endophytic organism. Specific strains of S. plymuthica produce a broad palette of antimicrobial compounds and might hold great potential as broad-spectrum biocontrol agents. This review surveys the advances of biocontrol research with respect to plant-associated S. plymuthica strains focusing on the principles and mechanisms of action of S. plymuthica and their use or potential use for the biological control of fungal plant diseases. A cursory overview of the taxonomy and ecology of S. plymuthica is also provided. We highlight recent progress in the identification of antifungal secondary metabolites produced by $S$. plymuthica and pay special attention to the regulatory mechanisms underpinning the production of the latter metabolites. Finally, we discuss several strategies that may provide a basis to improve the efficacy of S. plymuthica-mediated biocontrol.
\end{abstract}

Keywords: Serratia plymuthica, Biocontrol, Fungal pathogens, Post-harvest, Mechanisms

Review Methodology: We searched the following databases: CAB Abstracts and Web of Science (keyword search terms used: Serratia plymuthica, biocontrol, biological control, post-harvest). In addition, we used the references from the articles obtained by this method to check for additional relevant material.

\section{Taxonomy and Ecology}

The genus Serratia is named after the Italian physicist Serafino Serrati and belongs to the family Enterobacteriaceae within the Gammaproteobacteria. The only Serratia species recognized in the 8th edition of Bergey's Manual was Serratia marcescens [1]. In their paper about the taxonomy of Serratia, Grimont and co-workers [2] described four species within the genus Serratia: S. marcescens, Serratia liquefaciens, Serratia plymuthica and Serratia marinorubra (now called Serratia rubidaea). Nowadays, recognized species within the genus Serratia are S. marcescens, the $S$. liquefaciens complex (S. liquefaciens, Serratia proteamaculans and Serratia grimesii) [3]; the so-called 'unusual Serratia species [4]: Serratia ficaria [5], Serratia fonticola [6], Serratia odorifera [7], S. plymuthica, S. rubidaea [8] and Serratia entomophila [9]; and Serratia quinivorans [10].

The Serratia species are ubiquitous and can be found in water, soil, plants and animals (including humans). Serratia is an opportunist that has been recognized as a human pathogen only since the 1960s. S. marcescens and the S. liquefaciens complex are routinely associated with human infections, but also the 'unusual' Serratia spp. (except S. entomophila) have been described as causing human disease. 
S. plymuthica (Lehmann and Neumann [11]) Breed et al. $[12]$ has been found in soil $[13,14]$, water $[15,16]$ the air of poultry fattening houses [17], insects [15, 18-20] as an opportunistic pathogen in fish $[21,22]$ and on cold smoked rainbow trout [23] and fresh tuna fish [24]. In addition, $S$. plymuthica has been isolated from blood cultures, surgical wound exudates, the peritoneal fluid, infections of bone marrow, central venous catheters and a human burn site [25-30]. In general, S. plymuthica is considered to cause nosocomial infections, which means infections as a result of treatment in the hospital. However, we would like to insert a word of caution on the interpretation of these data. Although S. plymuthica has frequently been recovered from the human body, it was rarely isolated as the sole bacterial species present. Based on an international approved German directive (TRBA 466), S. plymuthica is nowadays classified into risk group 1 by the DSMZ (German Collection of Micro-organisms and Cell Cultures), indicating that the species does not inadvertently pose a threat to human health. In contrast to S. marcescens, which belongs to risk group 2 , there is no compelling evidence that $S$. plymuthica is capable of causing human infections. Furthermore, no pathogenicity factors have been identified so far and, in contrast to other nosocomial pathogens like Burkholderia and Stenotrophomonas, S. plymuthica does not inflict disease in alternative animal model systems such as the Caenorhabditis elegans assay [31].

S. plymuthica, however, is most frequently associated with plants. This organism has been isolated from the rhizosphere of grass [32], wheat [33], maize [34], oilseed rape [35], grape [36], melon [37], onion [38], Brassica sp. [39], Cichorium intybus [4], sugarbeet [40], tomato [41] and as an endophyte from the endorhiza of potato [42]. It has been found on the edible parts of green onion, carrot and lettuce [3], on the phyllosphere of spring wheat [43], on Brassica spp. [44] and as a contaminant in a raw vegetable processing line [45].

\section{S. plymuthica as a Biocontrol Agent of Fungal Plant Pathogens}

Over the last two decades, S. plymuthica has received steadily increasing attention as a biological control agent of mainly fungal pathogens. As such, S. plymuthica isolates have been used to control fungal soil-borne and leaf pathogens. Furthermore, some papers report the use of $S$. plymuthica to suppress post-harvest diseases. An overview of the S. plymuthica strains which have been reported to provide biocontrol of fungal plant pathogens ad planta is listed in Table 1.

\section{Using S. plymuthica to Control Soil-borne Diseases}

Since S. plymuthica strains are frequently associated with plant roots, they have most extensively been studied for their ability to control soil-borne fungal diseases.

S. plymuthica strain IC1270 from the rhizosphere of grapes, previously described as Enterobacter agglomerans [36] and later on attributed to S. plymuthica [46] effectively controlled Rhizoctonia solani damping-off of cotton [36], R. solani root rot of bean and Pythium aphanidermatum pre- and post-emergence damping-off on cucumber [46] under greenhouse conditions. Pythium disease severity was reduced to about two-thirds in the IC1270treated plants compared with control non-bacterized plants.

Over 5000 bacterial isolates from the roots of oilseed rape were screened for antifungal properties against Verticillium dahliae. Of the 146 active isolates that were determined, 18 isolates belong to the genus Serratia [35]. Of the 18 Serratia strains, 16 strains were identified as $S$. plymuthica. All the investigated isolates showed an antifungal activity against $V$. dahliae, $R$. solani and Sclerotinia sclerotiorum in bioassays [35]. One of the isolates from this study is the well-characterized S. plymuthica strain HROC48 (indicated as isolate C48 in [35] and as S. plymuthica strain DSMZ12502 in [55, 58]). Dipping strawberry roots in a suspension of $S$. plymuthica HRO-C48 reduced the percentage of Verticillium wilt by $18.5 \%$ and the percentage of Phytophtora cactorum root rot by $33.4 \%$. In three different field trials, Verticillium wilt was reduced compared with the non-treated control by an average of $24.2 \%$, whereas the average yield increase was $296 \%$. Phytophthora root rot was reduced by an average of $9.6 \%$, while the strawberry yield was increased by $60 \% \mathrm{com}$ pared with the non-treated control [55]. A commercial product on the basis of HRO-C48 has been developed (European patent 98124694.5 ) and called RhizoStar ${ }^{\circledR}$ (e-nema GmbH, Raisdorf, Germany).

S. plymuthica strain 3Re4-18 (indicated as S. plymuthica B4 in [52]) is an endophyte, isolated from the endorhiza of potato [42]. This isolate caused an average reduction of $25 \%$ in $R$. solani disease severity in two experiments on potato sprouts. Under field conditions, a disease suppression effect of $31 \%$ was achieved on potato, whereas the marketable tuber yield increased by up to $17 \% \mathrm{com}$ pared with the pathogen control. The strain was thus more effective in the field than in the pot experiments. Strain B4 was also used to control bottom rot on lettuce, caused by R. solani AG1-1B on leaf discs [53] and in two experimental fields. In both field experiments, soil application with the isolate increased the dry mass of lettuce by as much as $31 \%$ and reduced disease severity by $19 \%$ [52]. However, strain B4 was not effective in controlling damping-off disease caused by $R$. solani AG4 on sugarbeet seedlings [53].

Alström and Gerhardson [32] describe an isolate of S. plymuthica (G15), frequently isolated from roots of various plant species that showed strong antagonism against Botrytis cinerea and Gerlachia nivalis and moderate antagonism against $R$. solani, Fusarium culmorum and 
Table 1 Overview of S. plymuthica strains providing biocontrol of plant pathogens ad planta

\begin{tabular}{|c|c|c|c|}
\hline Strain & Plant & Pathogen & Reference \\
\hline \multirow[t]{12}{*}{ IC1270 } & Gossypium barbardense (cotton) & Rhizoctonia solani & [36] \\
\hline & Phaseolus vulgaris (bean) & R. solani & [46] \\
\hline & Cucumis sativus (cucumber) & Pythium aphanidermatum & [46] \\
\hline & Prunus persica (peaches) & Monilinia fructicola & [47] \\
\hline & & Rhizopus stolonifer & [47] \\
\hline & Pirus malus (apples) & Penicillium expansum & [47] \\
\hline & Citrus sinensis (oranges) & Penicillium digitatum & [48] \\
\hline & & Penicillium italicum & [48] \\
\hline & P. vulgaris (bean) & Colletotrichum lindemuthianum & [49] \\
\hline & P. vulgaris (bean) & Botrytis cinerea & [49] \\
\hline & Lycopersicon esculentum (tomato) & B. cinerea & [49] \\
\hline & Oryza sativa (rice) & Magnaporthe grisea & $\begin{array}{l}\text { (D. De Vleesschauwer } \\
\text { and M. Höfte, unpublished } \\
\text { results) }\end{array}$ \\
\hline \multirow[t]{4}{*}{ IC14 } & Citrus sinensis (oranges) & Penicillium digitatum & {$[48]$} \\
\hline & & $P$. italicum & [48] \\
\hline & C. sativus (cucumber) & B. cinerea & [37] \\
\hline & & Sclerotinia sclerotiorum & [37] \\
\hline \multirow[t]{2}{*}{ CL43 } & Dutch white cabbage & B. cinerea & [44] \\
\hline & & Alternaria brassicicola & {$[44]$} \\
\hline \multirow[t]{2}{*}{ R1GC4 } & C. sativus (cucumber) & P. aphanidermatum & [50] \\
\hline & C. sativus (cucumber) & Pythium ultimum & [51] \\
\hline \multirow[t]{3}{*}{$3 \operatorname{Re} 4-18^{1}$} & Solanum tuberosum (potato) & R. solani & [52] \\
\hline & Lactuca sativa (lettuce) & R. solani & [53] \\
\hline & Beta vulgaris (sugar beet) & R. solani & [53] \\
\hline R12 & Fragaria virginiana (strawberry) & Verticillium dahliae & [54] \\
\hline \multirow[t]{2}{*}{ HRO-C482 } & F. virginiana (strawberry) & V. dahliae & [55] \\
\hline & F. virginiana (strawberry) & Phytophtora cactorum & [55] \\
\hline \multirow[t]{2}{*}{$2-67$} & C. sativus (cucumber) & Colletotrichum orbiculare & [56] \\
\hline & Vitis (grape) & Eutypa lata & [57] \\
\hline B-781 & C. sativus (cucumber) & Pythium perplexum & [13] \\
\hline A21-4 & Capsicum annuum (pepper) & Phytophtora capsici & [38] \\
\hline
\end{tabular}

Strain 3Re4-18 was also designated B4.

${ }^{2}$ Strain HRO-C48 has been deposited as DZMZ12502.

Pythium sp. In addition, this isolate significantly increased growth of lettuce plants when applied to the roots under non-sterile conditions.

S. plymuthica strain A153 was isolated from the rhizosphere of wheat [33]. This strain was later on shown to suppress apothecia formation in S. sclerotiorum [59]. Inhibition of apothecial formation appears to be due to the production of chlorinated macrolides [59, 60]. Strain A153 has also been used for the biological control of weeds, both in the greenhouse [61] and the field [62].

The isolate S. plymuthica R1GC4 (origin could not be retraced) has been tested on rockwool-grown cucumbers for its ability to reduce Pythium root rot caused by P. aphanidermatum. Strain R1GC4 slightly increased the cumulative cucumber yields [50]. Benhamou et al. [51] also used this isolate in a later study in which the defence reactions of cucumber seedlings against Pythium ultimum with and without bacterial treatment were studied at the cellular level.

S. plymuthica strain A21-4 was isolated from the roots of onion and significantly inhibited mycelium growth, zoosporangia formation and cystospore germination of Phytophthora capsici in vitro. When pepper seedlings were dipped in a cell suspension of A21-4 and transplanted in the greenhouse, the bacteria successfully suppressed Phytophthora blight. Disease incidence 60 days after transplanting was $72.4 \%$ in the untreated plot, compared with $12.6 \%$ in the treated plants. A21-4 readily colonized the pepper roots and the bacterial density on the root was maintained above $10^{6} \mathrm{CFU} / \mathrm{g}$ root until 3 weeks after transplanting [38].

S. plymuthica strain B-781, which was isolated from a soil sample taken from the Burgundy region of France, effectively controlled damping-off disease of cucumber caused by Pythium perplexum [13].

\section{Using S. plymuthica to Control Fungal Post-harvest Diseases}

Only a few reports deal with the use of S. plymuthica to control post-harvest diseases. S. plymuthica CL43 (=S. plymuthica NCIMB40492), among other bacterial antagonists, has been used to control $B$. cinerea and Alternaria brassicicola on Dutch white cabbage at cold store temperature $[44,63,64]$. The S. plymuthica strains used 
Table 2 Overview of the production of biocontrol-related secondary metabolites by model S. plymuthica strains

\begin{tabular}{lllllll}
\hline & \multicolumn{2}{l}{ S. plymuthica strains } & & & \\
\cline { 2 - 7 } Metabolite & HRO-C48 & IC1270 & IC14 & A153 & R12 & 3Re4-18 \\
\hline Prodigiosin & - & - & - & ND & ND & ND \\
Haterumalides & ND & ND & ND & + & ND & ND \\
Pyrrolnitrin (Prn) & + & + & + & + & ND & ND \\
Glucanases & - & ND & - & ND & + & + \\
Chitinases & + & + & + & ND & + & + \\
Proteases & + & + & + & ND & ND & + \\
Siderophores & + & - & + & ND & ND & - \\
IAA & + & & & & & \\
\hline
\end{tabular}

$\mathrm{ND}=$ not determined.

showed in vitro and in vivo antagonism at $4^{\circ} \mathrm{C}$. The use of S. plymuthica CL43 and other bacteria to control postharvest diseases on cabbages is the subject of three different patents (US patents numbers 5780080, 5869038 and 5597565).

S. plymuthica strain IC1270 is an effective antagonist of Penicillium expansum (blue mould) on apple, and Monilia fructicola on peach [47]. In addition, this strain and S. plymuthica strain $\mathrm{IC} 14$, isolated from soil around melon roots [37] effectively suppressed Penicillium digitatum (green mould) and Penicillium italicum (blue mould) on orange [48]. Both strains reduced disease incidence by about $30 \%$ compared with control treatments.

\section{Using S. plymuthica to Control Fungal Leaf Pathogens}

Only S. plymuthica strains IC14 and IC1270 have been used for foliar application. Strain IC14 protected cucumber seedlings against $B$. cinerea grey mould and $S$. sclerotiorum white mould diseases of leaves under greenhouse conditions. Disease incidence was reduced by 76 and $84 \%$, respectively [37]. The survival ability of strain IC14 on cucumber leaves is limited, however. The titre of bacteria decreased from $1 \times 10^{6}$ cells per $0.5 \mathrm{~cm}^{2}$ of leaf tissue to $2.7 \times 10^{3}$ cells per $0.5 \mathrm{~cm}^{2}$ of leaf tissue after $72 \mathrm{~h}$. Leaf application with strain IC1270 decreased the number of B. cinerea spreading lesions from $92 \%$ in the control to $64 \%$, and from 78 to $48 \%$ in bean and tomato, respectively [49].

Some S. plymuthica strains, however, can induce systemic resistance in plants and control leaf pathogens when inoculated on plant roots. Seed treatment with $S$. plymuthica strain 2-67 significantly reduced the number and diameter of lesions caused by Colletotrichum orbiculare on cucumber leaves in two of three trials under greenhouse conditions [56]. Soil and seed treatment with S. plymuthica strain IC1270 induced systemic resistance to $B$. cinerea on tomato and bean leaves and to Colletotrichum lindemuthianum on bean [49]. Effective root colonization resulted in a $35 \%$ disease severity reduction. Strain 1270 was also able to induce systemic resistance to Magnaporthe grisea and Xanthomonas oryzae pv. oryzae on rice, causing reductions in disease severity of as much as $50 \%$ (D. De Vleesschauwer and $M$. Höfte, unpublished results).

\section{Biocontrol Mechanisms}

A thorough understanding of the antimicrobial mechanisms employed by $S$. plymuthica is important for an efficient and long-lasting biocontrol. Rhizosphere competence and biocontrol activity of $S$. plymuthica are enabled by antibiosis, parasitism involving production of lytic enzymes, competition for nutrients and iron by secretion of siderophores, and induction of plant defence mechanisms. None of these mechanisms are mutually exclusive and frequently several modes of action are exhibited by a single $S$. plymuthica strain. For instance, the mode of action of strain HRO-C48 comprises a diverse set of biocontrol mechanisms facing both pathogen and host plant [65]. Table 2 presents an overview of the spectrum of biocontrol-associated secondary metabolites produced by model strains of $S$. plymuthica.

\section{Antibiosis}

The production of organic antimicrobial secondary metabolites as a biocontrol mechanism of S. plymuthica has become increasingly better understood over the past decade. A variety of antibiotics have been identified, including compounds such as pyrrolnitrin (Prn), prodigiosin, the dipeptide antibiotic CB-25-I, 1-acetyl-7-chloro$1-\mathrm{H}$-indole and haterumalides $[32,35-37,58,59,60$, 66, 67].

Few S. plymuthica strains produce the non-diffusible red pigment and antifungal antibiotic prodigiosin [32, 35-37, 58]. Pigmented S. plymuthica biotypes, which were rarely isolated from plants, seem to be toxic to protozoa [68]. Hence, production of prodigiosin might offer an ecological advantage in widely diverse ecological niches. However, a correlation between the production of prodigiosin and 
the level of resistance to several antibiotics, as has been demonstrated for S. marcescens [68], could not be confirmed for S. plymuthica [58].

The chlorinated macrolides, haterumalide NA, B, NE and $X$, were among the first polyketide substances found to be produced by isolates belonging to the genus Serratia $[59,60]$. Isolated haterumalides, purified from the supernatant of S. plymuthica strain A153, strongly suppressed apothecial formation, ascospore germination and mycelial growth of several filamentous fungi and oomycetes in vitro $[60,69]$. Haterumalides NA, B and NE were also isolated from an Okinawan Ircinia sponge as inhibitors of the cell division of fertilized sea urchin eggs [70]. Structural similarities to other compounds suggest that the biosynthetic pathway of the haterumalides involves a type I polyketide synthase cluster, similar to the haterumalide biosynthesis in bacteria from the genus Pseudomonas [71, 72]. Nevertheless, further research regarding the genetic origin of haterumalides and the underlying biosynthetic pathway is needed to confirm the involvement of a type I polyketide synthase cluster in the biosynthesis of haterumalide antibiotics by S. plymuthica.

Prn [3-chloro-4-(2' -nitro-3' -chlorophenyl) pyrrole] is a tryptophan-derived secondary metabolite that has been reported to suppress a wide range of fungal and bacterial pathogens (for review see [73]). Although a vast amount of isolated S. plymuthica strains has been demonstrated to produce Prn in vitro [35, 37, 60, 67], several studies showed discrepancies regarding the role of Prn in the antagonistic activity of $S$. plymuthica strains. While Prn production was assumed to be a key factor of $S$. plymuthica IC1270-mediated biocontrol of several fungal post-harvest pathogens of peaches and apples [47], no evidence was found for the involvement of Prn in postharvest control of blue and green mould by the same strain [48]. Likewise, IC1270-triggered resistance against B. cinerea was shown to be independent of Prn, whereas Prn was demonstrated to play a prevalent role in direct antagonism towards distinct pathogens by the latter strain $[49,74]$. However, these conflicting observations can be reconciled when considering that many biocontrol strains produce a pallet of secondary antimicrobial metabolites and that conditions favouring one compound may not favour another [75]. This varied arsenal of biocontrol traits may enable antagonists to efficiently fine-tune their biocontrol activity and perform their ultimate objective of pathogen suppression under a wide range of environmental conditions. As such, different mechanisms or combinations of mechanisms may be involved in the suppression of different plant diseases by a particular biocontrol agent [76].

Because Prn production is an important biocontrol mechanism against several plant pathogens, extensive work has been carried out to elucidate its gene expression and regulation in the model strain Pseudomonas fluorescens Pf-5. In addition to the identification of the Prn biosynthetic gene operon, which comprises four genes $[77,78]$, Prn has been reported to be under global genetic control by a two-component regulatory system composed of the sensor protein ApdA (also called LemA) [79] and the response regulator GacA [80, 81]. Moreover, a gene necessary for Prn production has been identified as rpos, which encodes the stationary-phase sigma factor sigma(s) [71, 82]. The interactions between the RpoS and the GacS/GacA regulons are, however, poorly understood. Elegant research by Ovadis et al. [83] demonstrated the involvement of rpoS and gacA/lemA homologues (tentatively designated grrA/grrS for global response regulation activator/sensor) in Prn regulation in S. plymuthica strain IC1270. Prn-deficient grrA, grrS and rpoS gene replacement mutants were markedly less capable of suppressing $R$. solani and $P$. aphanidermatum under greenhouse conditions, indicating that IC1270mediated biocontrol is tightly modulated by the GrrA/ GrrS global regulatory cascade and the sigma factor RpoS. In addition, Prn biosynthesis was very recently demonstrated to be subject to positive control by a Luxl/LuxRtype quorum-sensing system consisting of an $\mathrm{N}$-acylhomoserine lactone (AHL) synthase (Spll) and an AHLresponsive cognate transcriptional repressor, designated as SpIR [84]. Using an AHL and Prn double-negative mutant of strain HRO-C48, which was deficient in suppressing the growth of several fungal plant pathogens in vitro, the authors provided evidence for the involvement of quorum-sensing signalling in biocontrol exerted by S. plymuthica.

\section{Parasitism}

Parasitism relies on the excretion of extracellular cell wall-degrading enzymes, such as chitinases, proteases and $\beta-1,3$-glucanases that can lyse pathogen cell walls [85].

Chitin, an insoluble $\beta$ - $(1,4)$-linked polymer of $N$-acetyl D-glucosamine (GlcNAc), is a ubiquitous component of most fungal cell walls. Chitinases, which catalyse the hydrolysis of chitin, can be classified into two major categories. Endochitinases (EC 3.2.1.14) cleave chitin randomly at internal sites, generating low molecular mass multimers of GIcNAc, such as chitotetraose, chitotriose and diacetylchitobiose. Exochitinases can be divided into two subcategories: chitobiosidases (EC 3.2.1.29) catalyse the progressive release of diacetylchitobiose units starting at the non-reducing end of chitin microfibrils, and $N$-acetyl- $\beta$-(1,4)-D-glucosaminidases (EC 3.2.1.30), which cleave the oligomeric products of endochitinases and chitobiosidases, generating monomers of GlcNAc [86]. Based on this system of nomenclature, several types of chitinases have been identified in S. plymuthica strains. Strain IC1270 produces two $N$-acetyl- $\beta$-D-glucosaminidases of 89 and $67 \mathrm{kDa}$, an endochitinase with a molecular mass of $59 \mathrm{kDa}$ and a $50 \mathrm{kDa}$ chitobiosidase. Strains IC14 
and $\mathrm{HRO}-\mathrm{C} 48$, on the other hand, have been reported to secrete an endochitinase and a $100 \mathrm{kDa} N$-acetyl- $\beta$ - 1,4 -Dhexosaminidase or chitobiase [37, 87].

To date, only one chitinase-encoding gene from S. plymuthica has been cloned [88]. Sequencing of the cloned gene chiA, which encodes the endochitinase from strain IC1270, yielded an open reading frame coding for 562 amino acids of a $61 \mathrm{kDa}$ precursor protein with a putative leader peptide at the $\mathrm{N}$ terminus. Homology modelling of the deduced enzyme's three-dimensional structure revealed high structural similarities with the corresponding enzyme from $S$. marcescens. Both structures consisted of an all- $\beta$-strand amino-terminal fibronectin III (FnIII)type domain, an $\alpha+\beta$ fold domain, and an $\alpha / \beta$-barrel domain. While it has been suggested that the first domain facilitates the binding of chitinase to chitin, the last domain is catalytic, retaining the conserved residues Glu315 and Asp391, which are located in the active site [88]. The antifungal activity of the secreted endochitinase was demonstrated in vitro using recombinant DNA techniques. The recombinant strain Escherichia coli JM109/pCHITEa1, expressing the $S$. plymuthica chiA gene, acquired the ability to suppress $R$. solani and spore germination of Fusarium oxysporum f. sp. meloni in vitro. Furthermore, the transformed strain also abrogated root rot disease caused by $R$. solani in cotton seedlings under greenhouse conditions [88].

The $58 \mathrm{kDa}$ endochitinase of S. plymuthica IC14 (ChiA) differs from this of strain IC1270 in that it not only hydrolyses chitin but also EGC, a chitin derivative usually used as a test substrate for lysozyme activity, suggesting that IC14 ChiA belongs to the class of bifunctional chitinase/lysozyme enzymes [37]. Such bifunctional enzymes have been suggested to enable bacteria to compete efficiently with fungi and other bacteria in a limited-nutrient environment. Alternatively, broader substrate specificity of chitinases has been related to other aspects of their function such as modulating the intricate relationships between biocontrol bacteria and their host organism [37].

So far, research aimed at elucidating the regulatory mechanisms underlying chitinase production in $S$. plymuthica has been confined to a limited number of strains. The GacS/GacA two-component system has previously been shown to positively regulate the expression of genes coding for secreted enzymes such as chitinases in a group of root-colonizing, plant-beneficial bacteria including Pseudomonas chlororaphis PCL1391 and P. fluorescens BL915 (for review see [89]). GrrA and grrS gene replacement mutants of IC1270, however, were deficient in production of the $58 \mathrm{kDa}$ ChiA endochitinase but not in that of the 89 and $67 \mathrm{kDa}$ exochitinases. As the rpoS mutant of IC1270 still secretes ChiA, the mutation in grrA or grrS is unlikely to exert its effect via repression of the stationary sigma factor RpoS, whose expression is positively regulated by the GacS/GacA system in $P$. fluorescens strain Pf-5 [90] and E. coli [91]. In addition, regulation of chitinase production seems to act independently of the quorum sensing machinery of IC1270 because synthesis of $\mathrm{AHL}$ signal molecules was blocked in both rpoS and grrA/ grrS gene replacement mutants [83]. However, Müller et al. [65] very recently reported that expression of chitinase is regulated positively by quorum sensing in strain HRO-C48. Likewise, an extracellular chitinase in S. plymuthica strain RVH1 is synthesized under the positive control of the SpllR quorum-sensing system [92], suggesting that the regulatory cascades that modulate chitinase production are strain-specific. Recently, it has been demonstrated that the GacS/GacA system partly steers its effects via post-transcriptional control exerted by small regulatory RNAs such as RsmB, RsmZ and Rsm Y [93, 94]. In Erwinia carotovora subsp. carotovora and P. fluorescens, these regulatory RNAs sequester the RNA-binding protein RsmA and thereby relieve translational repression of target mRNAs. Based on the taxonomic resemblance between S. plymuthica and E. carotovora, Ovadis et al. [83] hypothesize that translation of ChiA mRNAs involves similar post-transcriptional regulators.

Several studies have investigated the role of chitinases in biocontrol activity of S. plymuthica strains. Chitinases produced by S. plymuthica HRO-C48 played an important role in the antifungal activity of the latter strain both in dual culture assay and ad planta [87, 95]. However, chitinolytic activity appears less essential for S. plymuthica IC14; when used to suppress $S$. sclerotiorum and B. cinerea, synthesis of proteases and other biocontrol traits were involved [37]. Likewise, S. plymuthica IC1270-mediated biocontrol against $R$. solani and $P$. aphanidermatum was demonstrated to be independent of chitinase production [74]. Similar results were obtained in IC1270-modulated biocontrol assays with different post-harvest pathogens $[47,48]$. Hence, the contribution of chitinolytic activity in S. plymuthica-mediated biocontrol is clearly strain-specific and further illustrates the heterogeneous multifaceted character of biocontrol mechanisms employed by distinct bacterial strains against a diverse set of pathogens.

Glucanases and proteases are cell-wall degrading enzymes that are produced by a wide range of $S$. plymuthica strains $[35,37,42,53,96]$. However, to date, no studies regarding the regulation or precise role of these antifungal compounds in biocontrol by $S$. plymuthica have been conducted.

\section{Competition for Iron and the Role of Siderophores}

Iron is an essential growth element for all living organisms. The scarcity of bioavailable iron in soil habitats and on plant surfaces foments a furious competition [97]. Under iron-limiting conditions, bacteria produce a range of lowmolecular-weight compounds or siderophores to competitively acquire ferric iron. These bacterial iron chelators are thought to sequester the limited supply of iron available in the rhizosphere, thereby depriving pathogenic fungi of this essential element and consequently restricting 
their growth [98, 99]. Several S. plymuthica strains including IC1270, IC14, 3Re4-18 and HRO-C48, have been shown to secrete potent siderophores in vitro when grown on iron-poor media [35, 37, 42, 46, 53, 95]. Additionally, the residual biocontrol activity of distinct Prn- and/or endochitinase-negative mutants of IC1270 has been partially attributed to the unaltered ability of the latter strains to compete for nutrients such as iron $[74,83]$. Nevertheless, more detailed studies using siderophore-deficient mutants and application of purified compounds will be required to unequivocally delineate the involvement of bacterial iron chelators in S. plymuthica-mediated biocontrol.

\section{Induction of Plant Resistance Mechanisms}

An additional mechanism by which $S$. plymuthica can reduce plant diseases is by activating the host plant's defensive repertoire. Although the concept of rhizobacteria-mediated systemic resistance (Induced Systemic Resistance, ISR) has received increasing attention over the last decade, reports about $S$. plymuthica strains mounting systemic resistance are scarce. Gang et al. [56] first reported evidence that the $S$. plymuthica strain 2-67 induces ISR in cucumber to $C$. orbiculare. Further evidence showing the ISR-triggering capacity of S. plymuthica was provided by Benhamou et al. [51]. Using electron microscopy, the authors demonstrated that Pythium-challenged induced cucumber root cells undergo significant ultrastructural and biochemical modifications that correlate with the formation of structural barriers that likely prevent pathogen ingress towards the vascular stele accompanied by the deposition of a phenolic-enriched occluding material. Such responses associated with the onset of induced resistance would include the oxidation and polymerization of pre-existing phenols and the synthesis of new phenolic compounds via an activation of the phenylpropanoid pathway. Hence, S. plymuthica R1CG4 reduces Pythium root rot by priming susceptible cucumbers plants to elaborate a wide range of defence mechanisms. Recently, S. plymuthica strain IC1270 was shown to mount ISR against $B$. cinerea and $C$. lindemuthianum in bean and tomato [49]. In rice, however, IC1270 plays an ambivalent role in mounting induced resistance responses. While IC1270 conferred enhanced resistance to $M$. grisea and the bacterial pathogen $X$. oryzae pv. oryzae, bacterial colonization significantly promoted subsequent infection with the necrotrophic pathogens $R$. solani and Bipolaris oryzae. The differential effectiveness of IC1270 with respect to ISR-mediated disease resistance in rice is most likely due to its capacity to modulate the plant's oxidative machinery. Biochemical and histochemical studies demonstrated that IC1270 primes rice seedlings for a potentiated generation of reactive oxygen species in response to pathogen infection and wounding (D. De Vleesschauwer and $M$. Höfte, unpublished results).

\section{Phytostimulation}

Plant growth is affected by a plethora of abiotic and biotic factors. Most plant growth-promoting rhizobacteria (PGPRs) increase plant growth indirectly either by the suppression of well-established diseases caused by major pathogens or by reducing the deleterious effects of minor pathogens. Alternatively, PGPRs may directly affect plant metabolism resulting in increased plant growth, seed emergence or improved crop yield [85]. Several S. plymuthica strains have been demonstrated to exert plant growth-promoting effects in phytochamber, greenhouse and field trials $[53,55,96]$. The plant growth-stimulating ability of such strains has often been linked to their capacity to produce the auxin phytohormone indole-3acetic acid (IAA) in vitro. IAA is the main auxin in plants, controlling many fundamental physiological processes including cell enlargement and division, tissue differentiation, and responses to light and gravity [100, 101]. However, in several independent studies it was shown that IAA biosynthesis alone cannot account for the overall plant growth-promoting effect of Azospirillum [102]. Furthermore, Faltin et al. [53] found no correlation between IAA production in vitro and the plant growth-promoting effect on lettuce seedlings of several antagonistic bacteria, including the $S$. plymuthica strain 3Re4-18. In view of these data, the growth and yield promotion observed might be explained by the 'additive hypothesis' [103], postulating that growth promotion is the result of multiple coordinated mechanisms such as associative nitrogen fixation, modulation of phytohormonal balances, phytohormone biosynthesis and solubilization of phosphate. Thus, a balanced interplay of different factors including bacterial IAA biosynthesis rather than IAA production per se is most likely needed to stimulate plant growth. The use of mutant and transgenic strains and the analysis of inoculants' supernatant might shed more light on the diverse role played by different bacterial factors involved in S. plymuthica-mediated phytostimulation.

\section{Conclusions and Future Considerations}

Over the past two decades, several S. plymuthica strains have been demonstrated to be effective biocontrol agents against soil-borne and foliar diseases. Some S. plymuthica strains can also be used to control post-harvest diseases given their ability to antagonize pathogens at cold store temperatures [44, 63, 64]. In addition, S. plymuthica strains have been described as entomopathogens [104] and are employed for biological control of weeds [61, 62]. Many strains produce a variety of allelochemicals, including antibiotics, lytic enzymes and iron-chelating siderophores $[35,36,53,60,66,83]$. Moreover, the diverse origin of $S$. plymuthica isolates demonstrates that these bacteria are able to colonize widely diverse ecological niches. Hence, S. plymuthica strains might be ideal candidates for use as 
broad-spectrum biocontrol agents in integrated crop management.

Despite their potential as low-input practical agents of plant protection, widespread application of S. plymuthica strains as commercial biocontrol products has been hampered for several reasons such as the limited number of field tests conducted so far, the difficult formulation of the bacteria, and their emergence as facultative pathogens. Chief among concerns is the often-reported inconsistent performance of biocontrol agents in the field, which is usually attributed to their poor rhizosphere competence [105]. Biocontrol strains can only be used optimally if the molecular basis of their beneficial effects, and the way these traits are influenced by a myriad of biotic and abiotic factors, are unravelled. As many studies have demonstrated discrepancies between the antagonistic potential of the biocontrol agent in vitro and its efficacy under field conditions [53], successful reproducible biocontrol on the basis of plant-associated S. plymuthica also requires profound knowledge of the ecological and molecular interplay taking place in bacterial communities in order to predict the conditions under which biocontrol can be achieved. Revelations about the modes of action of S. plymuthica biocontrol strains will open new doors to design strategies for improving the efficacy of biocontrol products [106]. For instance, identifying different modes of action will facilitate the combination of biocontrol strains to hit pathogens with a broader spectrum of microbial weapons [107, 108]. Identification of key antimicrobials produced by S. plymuthica, such as chitinases or Prn, and elucidation of their biosynthetic pathways can be exploited for streamlining biocontrol strain discovery by targeting selection of new isolates that carry relevant biosynthetic genes [109].

Despite the fact that genotypic and phenotypic diversity occurring in natural populations of biocontrol agents provides an enormous resource for improving biological control of plant diseases [110], exploitation of such diversity among bacterial biocontrol agents of fungal plant pathogens has received little attention. Yet, knowledge of the diversity within a group of strains sharing a common biocontrol trait can be exploited to select biocontrol strains that are superior with respect to rhizosphere competence and biocontrol activity. Recent studies by Berg [58] demonstrated that populations of plant-associated and antifungal $S$. plymuthica strains can be highly diverse and thus have great potential for improving biological control. For instance, by matching bacterial genotypes with crops or varieties for which they have a preference, genotypic differences among strains could be exploited to face the biotic and abiotic complexity of natural environments.

A salient feature of $S$. plymuthica is that some strains are able to colonize the endorhiza [42]. Given the intimate relationships with their hosts, endophytic bacteria hold great potential to further our understanding of the multiple facets of disease suppression. As indicated by
Compant et al. [107], continued work with endophytic bacteria might play a fundamental role in the development of biocontrol agents that are self-perpetuating by colonizing hosts and being transferred to progeny much as is the case with the non-symbiotic endophyte bacterium Burkholderia phytofirmans PsJN [111] or associative nitrogen-fixing bacteria on sugar cane [112].

\section{Acknowledgements}

Serratia research in our laboratory is supported by a specialization fellowship of the Flemish Institute for the Stimulation of Scientific-Technological Research in Industry (IWT, Belgium) given to David De Vleesschauwer and by a grant from the Special Research Fund of Ghent University, Belgium.

\section{References}

1. Buchanan R, Gibbons N. Bergey's Manual of Determinative Bacteriology. 8th ed. Williams and Wilkins, Baltimore, USA; 1974.

2. Grimont PAD, Grimont F, Dulongderosnay HLC, Sneath PHA. Taxonomy of genus Serratia. Journal of General Microbiology 1977;98:39-66.

3. Grimont PAD, Grimont F, Starr MP. Serratia species isolated from plants. Current Microbiology 1981;5:317-22.

4. Stock I, Burak S, Sherwood KJ, Gruger T, Wiedemann B. Natural antimicrobial susceptibilities of strains of 'unusual' Serratia species: S. ficaria, S. fonticola, S. odorifera, S. plymuthica and S. rubidaea. Journal of Antimicrobial Chemotherapy 2003;51:865-85.

5. Grimont PAD, Grimont F, Starr MP. Serratia ficaria sp. nov. a bacterial species associated with Smyrna figs and the fig wasp Blastophaga psenes. Current Microbiology 1979;2:277-82.

6. Gavini F, Ferragut C, Izard D, Trinel PA, Leclerc H, Lefebvre B, et al. Serratia fonticola, a new species from water. International Journal of Systematic Bacteriology 1979;29:92-101.

7. Grimont PAD, Grimont F, Richard C, Davis BR, Steigerwalt AG, Brenner DJ. Deoxyribonucleic acid relatedness between Serratia plymuthica and other Serratia species with description of Serratia odorifera sp. nov. (type strain ICPB 3995). International Journal of Systematic Bacteriology 1978;28: 453-63.

8. Ewing WH, Davis BR, Fife MA, Lessel EF. Biochemical characterization of Serratia liquefaciens (Grimes and Hennerty) Bascomb and Al (formerly Enterobacter liquefaciens) and Serratia rubidaea (Stapp) Comb Nov and designation of type and neotype strains. International Journal of Systematic Bacteriology 1973;23:217-25.

9. Grimont PAD, Jackson TA, Ageron E, Noonan MJ. Serratia entomophila sp. nov. associated with amber disease in the New Zealand grass grub Costelytra zealandica. International Journal of Systematic Bacteriology 1988;38:1-6.

10. Ashelford KE, Fry JC, Bailey MJ, Day MJ. Characterization of Serratia isolates from soil, ecological implications and transfer of Serratia proteamaculans subsp. quinovora 
Grimont et al. 1983 to Serratia quinivorans corrig., sp. nov. International Journal of Systematic and Evolutionary Microbiology 2002;52:2281-9.

11. Lehmann KB, Neumann R. Atlas und grundriss der bakteriologie und lehrbuch der speciellen bakteriologischen diagnostik. 1896. Munich, Lehmann. p. 448.

12. Breed RS, Murray EGD, Hitchens AP. Bergey's Manual of Determinative Bacteriology. 6th ed. Williams and Wilkins, Baltimore, USA; 1948.

13. Galland D, Paul B. Pythium perplexum isolated from soil in France: morphology, molecular characterisation and biological control. Microbiological Research 2001;156:185-9.

14. Grant RJ, Daniell TJ, Betts WB. Isolation and identification of synthetic pyrethroid-degrading bacteria. Journal of Applied Microbiology 2002;92:534-40.

15. Grimont PAD, Grimont F. Genus Serratia. Annual Review of Microbiology 1978;32:221-48.

16. Vivas J, Gonzalez JA, Barbeyto L, Rodriguez LA. Identification of environmental Serratia plymuthica strains with the new Combo panels type 1S. Memorias Do Instituto Oswaldo Cruz 2000;95:227-9.

17. Vucemilo M, Vinkovic B, Tofant A, Simpraga B, Pavicic, Matkovic K. 2005. Microbiological air contamination in intensive poultry breeding. In: Krynski A, Wrzesien R. Animals and environment. Proceedings of the XIIth ISAH Congress on Animal Hygiene, 4-8 September 2005, Warsaw, Poland; 2005. p. 127-9.

18. Kobayashi N, Ichikawa $\mathrm{Y}$. Inverse relationships between the flagella formation and prodigiosin synthesis in Serratia marcescens. Microbiology and Immunology 1990;34:347-54.

19. Stojek NM, Dutkiewicz J. Studies on the occurrence of gramnegative bacteria in ticks: Ixodes ricinus as a potential vector of Pasteurella. Annals of Agricultural and Environmental Medicine 2004;11:319-22.

20. Tothprestia C, Hirshfield IN. Isolation of plasmid-harboring Serratia plymuthica from facultative gut microflora of the tobacco hornworm, Manduca Sexta. Applied and Environmental Microbiology 1988;54:1855-7.

21. Austin B, Stobie M. Recovery of Serratia plymuthica and presumptive Pseudomonas pseudoalkaligenes from skinlesion in rainbow-trout, Oncorhynchus mykiss (Walbaum), otherwise infected with enteric redmouth. Journal of Fish Diseases 1992;15:541-3.

22. Nieto TP, Lopez LR, Santos Y, Nunez S, Toranzo AE. Isolation of Serratia plymuthica as an opportunistic pathogen in rainbow-trout. Journal of Fish Diseases 1990;13:175-7.

23. Lyhs U, Bjorkroth J, Hyytia E, Korkeala $H$. The spoilage flora of vacuum-packaged, sodium nitrite or potassium nitrate treated, cold-smoked rainbow trout stored at 4 degrees $\mathrm{C}$ or 8 degrees C. International Journal of Food Microbiology 1998;45:135-42.

24. López-Sabater EI, Rodriguez-Jerez JJ, Roig-Sagués AX Mora-Ventura MT. Bacteriological quality of tuna fish (Thunnus thynnus) destined for canning; effect of tuna handling on presence of histidine decarboxylase bacteria and histamine level. In: Ingkaninun P, Poomises P, editors. Proceedings of the 11 th International Symposium of the World Association of Veterinary Food Hygienists, 24-29 October 1993, Bangkok, Thailand; 1993. p. 366-9.
25. Carrero P, Garrote JA, Pacheco S, Garcia Al, Gil R, Carbajosa SG. Report of 6 cases of human infection by Serratia plymuthica. Journal of Clinical Microbiology 1995;33:275-6.

26. Clark RB, Janda JM. Isolation of Serratia plymuthica from a human burn site. Journal of Clinical Microbiology 1985;21:656-7.

27. Domingo D, Limia A, Alarcon T, Sanz JC, Delrey MC, Lopezbrea M. Nosocomial septicemia caused by Serratia plymuthica. Journal of Clinical Microbiology 1994;32:575-7.

28. Horowitz HW, Nadelman RB, Vanhorn KG, Weekes SE, Goyburu L, Wormser GP. Serratia plymuthica sepsis associated with infection of central venous catheter. Journal of Clinical Microbiology 1987;25:1562-3.

29. Reina J, Borrell N, Llompart I. Community-acquired bacteremia caused by Serratia plymuthica - case report and review of the literature. Diagnostic Microbiology and Infectious Disease 1992;15:449-52.

30. Zbinden R, Blass R. Serratia plymuthica osteomyelitis following motorcycle accident. Journal of Clinical Microbiology 1988;26:1409-10.

31. Berg G. Serratia plymuthica HRO C-48 - Safety Issues. Available from: URL: www.rebeca-net.de/downloads/ Pathogenity\%20of\%20Serratia\%20C48.pdf.

32. Alstrom S, Gerhardson B. Characteristics of a Serratia plymuthica isolate from plant rhizospheres. Plant and Soil 1987;103:185-9.

33. Astrom B, Gerhardson B. Differential reactions of wheat and pea genotypes to root inoculation with growth-affecting rhizosphere bacteria. Plant and Soil 1988;109:263-9.

34. Lucon CMM, Melo IS. Effect of seed bacterization on the development of maize plants and Fusarium moniliforme control. Fitopatologia Brasileira 2000;25:529-37.

35. Kalbe C, Marten P, Berg G. Strains of the genus Serratia as beneficial rhizobacteria of oilseed rape with antifungal properties. Microbiological Research 1996;151:433-9.

36. Chernin L, Ismailov Z, Haran S, Chet I. Chitinolytic bacteria Enterobacter agglomerans antagonistic to fungal plantpathogens. Applied and Environmental Microbiology 1995;61:1720-6.

37. Kamensky M, Ovadis M, Chet I, Chernin L. Soil-borne strain IC14 of Serratia plymuthica with multiple mechanisms of antifungal activity provides biocontrol of Botrytis cinerea and Sclerotinia sclerotiorum diseases. Soil Biology and Biochemistry 2003;35:323-31.

38. Park C, Shen S. Biocontrol of phytophthora blight of pepper employing Serratia plymuthica A21-4 and effect of soil population of Phytophthora capsici on the root colonization of the antagonistic bacteria. Bulletin OILB/SROP 2002;25: 327-30.

39. Carlot M, Giacomini A, Casella S. Aspects of plant-microbe interactions in heavy metal polluted soil. Acta Biotechnologica 2002;22:13-20.

40. Tenning P, Rijsbergen RV, Messens A, Vriendt JD, Zhao Y, Leyns $F$, et al. Antifungal activities produced by a Serratia plymuthica. Mededelingen van de Faculteit Landbouwwetenschappen, Rijksuniversiteit Gent 1987;52:1133-8.

41. Frommel MI, Pazos GS, Nowak J. Plant-growth stimulation and biocontrol of Fusarium wilt (Fusarium oxysporum f. sp. 
lycopersici) by co-inoculation of tomato seeds with Serratia plymuthica and Pseudomonas sp. Fitopatología 1991;26: 66-73.

42. Berg G, Krechel A, Ditz M, Sikora RA, Ulrich A, Hallmann J. Endophytic and ectophytic potato-associated bacterial communities differ in structure and antagonistic function against plant pathogenic fungi. FEMS Microbiology Ecology 2005;51:215-29.

43. Legard DE, McQuilken MP, Whipps JM, Fenlon JS, Fermor TR, Thompson IP, et al. Studies of seasonal changes in the microbial populations on the phyllosphere of spring wheat as a prelude to the release of a genetically modified microorganism. Agriculture, Ecosystems \& Environment 1994;50:87-101.

44. Leifert C, Sigee DC, Stanley R, Knight C, Epton HAS. Biocontrol of Botrytis cinerea and Alternaria brassicicola on Dutch white cabbage by bacterial antagonists at cold-store temperatures. Plant Pathology 1993;42:270-9.

45. van Houdt $R$, Moons $P$, Jansen $A$, Vanoirbeek $K$, Michiels CW. Genotypic and phenotypic characterization of a biofilmforming Serratia plymuthica isolate from a raw vegetable processing line. FEMS Microbiology Letters 2005;246:265-72.

46. Ovadis M, Liu XG, Gavriel S, Ismailov Z, Chet I, Chernin L. The global regulator genes from biocontrol strain Serratia plymuthica IC1270: Cloning, sequencing, and functional studies. Journal of Bacteriology 2004;186:4986-93.

47. Ritte E, Lurie S, Droby S, Ismailov Z, Chet I, Chernin L. Biocontrol of postharvest fungal pathogens of peaches and apples by Pantoae agglomerans strain IC1270. Bulletin OILB/ SROP 2002;25:199-202.

48. Meziane H, Gavriel S, Ismailov Z, Chet I, Chernin L, Höfte M. Control of green and blue mould on orange fruit by Serratia plymuthica strains IC14 and IC1270 and putative modes of action. Postharvest Biology and Technology 2006;39: 125-33.

49. Meziane H, Chernin L, Höfte M. Use of Serratia plymuthica to control fungal pathogens in bean and tomato by induced resistance and direct antagonism. Bulletin OILB/SROP 2006;29:101-5.

50. McCullagh M, Utkhede R, Menzies JG, Punja ZK, Paulitz TC. Evaluation of plant growth-promoting rhizobacteria for biological control of Pythium root rot of cucumbers grown in rockwool and effects on yield. European Journal of Plant Pathology 1996;102:747-55.

51. Benhamou N, Gagné S, Quéré DI, Dehbi L. Bacterialmediated induced resistance in cucumber: beneficial effect of the endophytic bacterium Serratia plymuthica on the protection against infection by Pythium ultimum. Phytopathology 2000;90:45-56.

52. Grosch R, Faltin F, Lottmann J, Kofoet A, Berg G. Effectiveness of 3 antagonistic bacterial isolates to control Rhizoctonia solani Kühn on lettuce and potato. Canadian Journal of Microbiology 2005;51:345-53.

53. Faltin F, Lottmann J, Grosch R, Berg G. Strategy to select and assess antagonistic bacteria for biological control of Rhizoctonia solani Kühn. Canadian Journal of Microbiology 2004;50:811-20.

54. Berg G, Fritze A, Roskot N, Smalla K. Evaluation of potential biocontrol rhizobacteria from different host plants of
Verticillium dahliae Kleb. Journal of Applied Microbiology 2001;91:963-71.

55. Kurze S, Bahl H, Dahl R, Berg G. Biological control of fungal strawberry diseases by Serratia plymuthica HRO-C48. Plant Disease 2001;85:529-34.

56. Gang W, Kloepper JW, Tuzun S. Induction of systemic resistance of cucumber to Colletotrichum orbiculare by select strains of plant growth-promoting rhizobacteria Phytopathology 1991;81:1508-12.

57. Schmidt CS, Lorenz D, Wolf GA. Biological control of the grapevine dieback fungus Eutypa lata I: screening of bacterial antagonists. Journal of Phytopathology 2001;149:427-35.

58. Berg G. Diversity of antifungal and plant-associated Serratia plymuthica strains. Journal of Applied Microbiology 2000;88:952-60.

59. Thaning C, Welch CJ, Borowicz JJ, Hedman R, Gerhardson B. Suppression of Sclerotinia sclerotiorum apothecial formation by the soil bacterium Serratia plymuthica: identification of a chlorinated macrolide as one of the causal agents. Soil Biology and Biochemistry 2001;33:1817-26.

60. Levenfors JJ, Hedman R, Thaning C, Gerhardson B, Welch CJ. Broad-spectrum antifungal metabolites produced by the soil bacterium Serratia plymuthica A153. Soil Biology \& Biochemistry 2004;36:677-85.

61. Weissmann R. Plant growth-affecting bacteria as weed suppressing agents. Acta Universitatis Agriculturae Sueciae - Agraria; 2002.

62. Weissmann R, Uggla C, Gerhardson B. Field performance of a weed-suppressing Serratia plymuthica strain applied with conventional spraying equipment. BioControl 2003;48: 725-42.

63. Leifert C, Sigee DC, Epton HAS, Stanley R, Knight C. Isolation of bacteria antagonistic to postharvest fungal diseases of cold-stored Brassica spp. Phytoparasitica 1992;20:143-8.

64. Stanley R, Brown M, Poole N, Rogerson M, Sigee DC, Knight $\mathrm{C}$, et al. Biocontrol of post-harvest fungal diseases on Dutch white cabbage by Pseudomonas and Serratia antagonists in storage trials. Plant Pathology 1994;43:605-11.

65. Müller H, Liu X, Westendorf C, Bimerew M, Voloshina P, $\mathrm{Khmel} \mathrm{I}$, et al. Bidirectional mode of action of the biological control agent Serratia plymuthica HRO-C48 and the regulation by quorum sensing. In: Fundamental and practical approaches to increase biocontrol efficacy. Abstract book of the IXth meeting of the 'phytopathogens' group of OILB/ SROP, 6-10 september 2006, Spa, Belgium; 2006. p. 93.

66. Shoji J, Hinoo H, Sakazaki R, Kato T, Hattori T, Matsumoto K, et al. Isolation of CB-25-I, an antifungal antibiotic, from Serratia plymuthica. Journal of Antibiotics 1989;42:869-74.

67. Chernin L, Brandis A, Ismailov Z, Chet I. Pyrrolnitrin production by an Enterobacter agglomerans strain with a broad spectrum of antagonistic activity towards fungal and bacterial phytopathogens. Current Microbiology 1996;32:208-12.

68. Grimont F, Grimont, PAD. The genus Serratia. In: Balowes A, Trüper HG, Dworkin M, Harder W, Schleifer KH, editors. The Prokaryotes: A Handbook on the Biology of Bacteria: Ecophysiology, Isolation, Identification, Applications. 2nd ed. Springer, New York, USA; 1992. p. 2822-48. 
69. Strobel G, Li J, Sugawara F, Koshino H, Harper J, Hess WM. Oocydin A, a chlorinated macrocyclic lactone with potent antioomycete activity from Serratia marcescens. Microbiology 1999;145:3557-64.

70. Takada N, Sato H, Suenaga K, Arimoto H, Yamada K, Ueda $\mathrm{K}$, et al. Isolation and structures of haterumalides NA, NB, NC, ND, and NE, novel macrolides from an Okinawan sponge Ircinia sp. Tetrahedron Letters 1999;40:6309-12.

71. Nowak-Thompson B, Chaney N, Wing JS, Gould SJ, Loper JE. Characterization of the pyoluteorin biosynthetic gene cluster of Pseudomonas fluorescens Pf-5. Journal of Bacteriology 1999;181:2166-74.

72. Rangaswamy V, Jiralerspong S, Parry R, Bender CL. Biosynthesis of the Pseudomonas polyketide coronafacic acid requires monofunctional and multifunctional polyketide synthase proteins. Proceedings of the National Academy of Sciences of the United States of America 1998;95:15469-74.

73. Haas D, Keel C. Regulation of antibiotic production in rootcolonizing Pseudomonas spp. and relevance for biological control of plant disease. Annual Review of Phytopathology 2003;41:117-53.

74. Gavriel S, Ismailov Z, Ovadis M, Chet I, Chernin L. Comparative study of chitinase and pyrrolnitrin biocontrol activity in Serratia plymuthica strain IC1270. Bulletin OILB/ SROP 2004;27:347-50.

75. Duffy BK, Defago G. Environmental factors modulating antibiotic and siderophore biosynthesis by Pseudomonas fluorescens biocontrol strains. Applied and Environmental Microbiology 1999;65:2429-38.

76. Haas D, Defago G. Biological control of soil-borne pathogens by fluorescent pseudomonads. Nature Reviews Microbiology 2005;3:307-19.

77. Hammer PE, Hill DS, Lam ST, VanPee KH, Ligon JM. Four genes from Pseudomonas fluorescens that encode the biosynthesis of pyrrolnitrin. Applied and Environmental Microbiology 1997;63:2147-54.

78. Kirner S, Hammer PE, Hill DS, Altmann A, Fischer I, Weislo $\mathrm{LJ}$, et al. Functions encoded by pyrrolnitrin biosynthetic genes from Pseudomonas fluorescens. Journal of Bacteriology 1998;180:1939-43.

79. Corbell N, Loper JE. A global regulator of secondary metabolite production in Pseudomonas fluorescens Pf-5. Journal of Bacteriology 1995;177:6230-6.

80. Gaffney TD, Lam ST, Ligon J, Gates K, Frazelle A, Dimaio J, et al. Global regulation of expression of antifungal factors by a Pseudomonas fluorescens biological control strain. Molecular Plant-Microbe Interactions 1994;7:455-63.

81. Laville J, Voisard C, Keel C, Maurhofer M, Defago G, Haas D. Global control in Pseudomonas fluorescens mediating antibiotic synthesis and suppression of black root rot of tobacco. Proceedings of the National Academy of Sciences of the United States of America 1992;89:1562-6.

82. Sarniguet A, Kraus J, Henkels MD, Muehlchen AM, Loper JE. The sigma factor sigma(S) affects antibiotic production and biological control activity of Pseudomonas fluorescens Pf-5. Proceedings of the National Academy of Sciences of the United States of America 1995;92:12255-9.

83. Ovadis M, Liu X, Gavriel S, Ismailov Z, Chet I, Chernin L. The global regulator genes from biocontrol strain Serratia plymuthica IC1270: cloning, sequencing, and functional studies. Journal of Bacteriology 2004;186:4986-93.
84. Liu XG, Bimerew M, Ma YX, Mueller H, Ovadis M, Eberl L, et al. Quorum-sensing signaling is required for production of the antibiotic pyrrolnitrin in a rhizospheric biocontrol strain of Serratia plymuthica. FEMS Microbiology Letters 2007;270:299-305.

85. Whipps JM. Microbial interactions and biocontrol in the rhizosphere. Journal of Experimental Botany 2001;52: 487-511.

86. Patil RS, Ghormade V, Deshpande MV. Chitinolytic enzymes: an exploration. Enzyme and Microbial Technology 2000;26:473-83.

87. Frankowski J, Lorito M, Scala F, Schmid R, Berg G, Bahl H. Purification and properties of two chitinolytic enzymes of Serratia plymuthica HRO-C48. Archives of Microbiology 2001;176:421-6.

88. Chernin LS, DelaFuente L, Sobolev V, Haran S, Vorgias CE, Oppenheim AB, et al. Molecular cloning, structural analysis, and expression in Escherichia coli of a chitinase gene from Enterobacter agglomerans. Applied and Environmental Microbiology 1997;63:834-9.

89. Heeb S, Haas D. Regulatory roles of the GacS/GacA twocomponent system in plant-associated and other Gramnegative bacteria. Molecular Plant-Microbe Interactions 2001;14:1351-63.

90. Whistler CA, Corbell NA, Sarniguet A, Ream W, Loper JE. The two-component regulators GacS and GacA influence accumulation of the stationary-phase sigma factor sigma(S) and the stress response in Pseudomonas fluorescens Pf-5. Journal of Bacteriology 1998;180:6635-41.

91. Mukhopadhyay S, Audia JP, Roy RN, Schellhorn HE. Transcriptional induction of the conserved alternative sigma factor RpoS in Escherichia coli is dependent on BarA, a probable two-component regulator. Molecular Microbiology 2000;37:371-81.

92. Van Houdt R, Moons P, Aertsen A, Jansen A, Vanoirbeek K, Daykin $\mathrm{M}$, et al. Characterization of a luxl/luxR-type quorum sensing system and $\mathrm{N}$-acyl-homoserine lactone-dependent regulation of exo-enzyme and antibacterial component production in Serratia plymuthica RVH1. Research in Microbiology 2007;158:150-8.

93. Cui Y, Chatterjee A, Chatterjee AK. Effects of the twocomponent system comprising GacA and GacS of Erwinia carotovora subsp. carotovora on the production of global regulatory rsmB RNA, extracellular enzymes, and Harpin(Ecc). Molecular Plant-Microbe Interactions 2001;14:516-26.

94. Heeb S, Blumer C, Haas D. Regulatory RNA as mediator in GacA/RsmA-dependent global control of exoproduct formation in Pseudomonas fluorescens CHAO. Journal of Bacteriology 2002;184:1046-56.

95. Frankowski J, Berg G, Bahl H. Mechanisms involved in the antifungal activity of the rhizobacterium Serratia plymuthica. Bulletin OILB/SROP 1998;24:45-50.

96. Berg G, Fritze A, Roskot N, Smalla K. Evaluation of potential biocontrol rhizobacteria from different host plants of Verticillium dahliae Kleb. Journal of Applied Microbiology 2001;91:963-71.

97. Höfte M, Buysens S, Koedam N, Cornelis P. Zinc affects siderophore-mediated high-affinity iron uptake systems in the rhizosphere Pseudomonas aeruginosa 7NSK2. Biometals 1993;6:85-91. 
98. Loper JE, Henkels MD. Utilization of heterologous siderophores enhances levels of iron available to Pseudomonas putida in the rhizosphere. Applied and Environmental Microbiology 1999;65:5357-63.

99. O'Sullivan DJ, Ogara F. Traits of fluorescent pseudomonads spp. involved in suppression of plant-root pathogens. Microbiological Reviews 1992;56:662-76.

100. Teale WD, Paponov IA, Palme K. Auxin in action: signalling, transport and the control of plant growth and development. Nature Reviews Molecular Cell Biology 2006;7:847-59.

101. Woodward AW, Bartel B. Auxin: regulation, action, and interaction. Annals of Botany 2005;95:707-35.

102. Spaepen S, Vanderleyden J, Remans R. Indole-3-acetic acid in microbial and microorganism-plant signaling. FEMS Microbiology Reviews 2007;31:425-48.

103. Bashan Y, Holguin C. Azospirillum-plant relationships: Environmental and physiological advances (1990-1996). Canadian Journal of Microbiology 1997;43:103-21.

104. Tan B, Jackson TA, Hurst MRH. Virulence of Serratia strains against Costelytra zealandica. Applied and Environmental Microbiology 2006;72:6417-8.

105. Weller DM. Biological control of soilborne plant pathogens in the rhizosphere with bacteria. Annual Review of Phytopathology 1988;26:379-407.

106. Walsh UF, Morrissey JP, O'Gara F. Pseudomonas for biocontrol of phytopathogens: from functional genomics to commercial exploitation. Current Opinion in Biotechnology 2001;12:289-95.

107. de Boer M, van der Sluis I, van Loon LC, Bakker P. Combining fluorescent Pseudomonas spp. strains to enhance suppression of fusarium wilt of radish. European Journal of Plant Pathology 1999;105:201-10.

108. Olivain C, Alabouvette C, Steinberg C. Production of a mixed inoculum of Fusarium oxysporum Fo47 and Pseudomonas fluorescens $\mathrm{C} 7$ to control Fusarium diseases. Biocontrol Science and Technology 2004;14:227-38.

109. Compant S, Duffy B, Nowak J, Clement C, Barka EA. Use of plant growth-promoting bacteria for biocontrol of plant diseases: Principles, mechanisms of action, and future prospects. Applied and Environmental Microbiology 2005;71:4951-9.

110. Keel C, Weller DM, Natsch A, Defago G, Cook RJ, Thomashow LS. Conservation of the 2,4-

diacetylphloroglucinol biosynthesis locus among fluorescent Pseudomonas strains from diverse geographic locations. Applied and Environmental Microbiology 1996;62:552-63.

111. Sessitsch A, Coenye T, Sturz AV, Vandamme P, Barka EA, Salles JF, et al. Burkholderia phytofirmans sp. nov., a novel plant-associated bacterium with plant-beneficial properties. International Journal of Systematic and Evolutionary Microbiology 2005;55:1187-92.

112. Boddey RM, Urquiaga S, Alves BJR, Reis V. Endophytic nitrogen fixation in sugarcane: present knowledge and future applications. Plant and Soil 2003;252:139-49. 